\title{
Lymph node invasion by tumor cells modifies the distribution of dendritic cell subsets and memory $T$ cell profiles in human cancer patients
}

\author{
Nicolás Gonzalo Núñez , Ana Tereza Nadan, Louis Pérol, Maud Milder, Sophie Viel, \\ Philippe De La Rochere Philippe, Delphine Loirat, Sastre-Garau Xavier, Christine Sedlik, Sebastian Amigorena, \\ Eliane Piaggio
}

From Society for Immunotherapy of Cancer 29th Annual Meeting National Harbor, MD, USA. 6-9 November 2014

\section{Introduction}

In human breast cancer, the invasion of tumor-draining lymph nodes (TDLNs) is an important step in disease progression and has predictive value [1]. TDLN dendritic cells (DCs), which are comprised of lymphoid-organ-resident and skin-derived migratory DCs, present tumor antigens to the naïve $\mathrm{T}$ cells and induce their activation and polarization into different functional subsets (Th1, Th2, Th17, Th22, Tfh, regulatory $\mathrm{T}$ cells) that will lead to antitumor $\mathrm{T}$ cell responses or to tolerance [2].

\section{Objective}

Systematic comparison of the immune profile of Invaded (INV) versus Non-invaded (NI) TDLNs would help to identify those immunomodulatory mechanisms associated to the presence of the tumor that could condition the response to immunotherapy.

\section{Material and methods}

TDLNs from 70 untreated breast cancer patients undergoing surgery at Institut Curie Hospital were obtained in accordance with institutional ethical guidelines. Samples were analyzed by multi-color flow cytometry. For statistical analysis, Wilcoxon matched paired test or Mann-Whitney test was performed using Prism (GraphPadSoftware)

\section{Results}

We studied the distribution of 6 different DC subpopulations and observed in INV TDLNs a significant decrease in the percentage of BDCA1+ DCs $(P<0.05)$ and a significant increase in the percentage of
CD11c+HLADR + CD14+cells $(P<0.01)$, including macrophages and inflammatory DCs, compared to NI TDLNs $(P<0.05)$. We also found a significant lower frequency of naïve conventional and regulatory $\mathrm{T}$ cells in INV TDLNs $(P<0.05)$. Both, in NI and INV TDLNs, memory conventional and regulatory $\mathrm{T}$ cells were highly polarized, mainly to the Th1 phenotype, but also to the Th2, Th17, Tfh and Th22 phenotypes, as determined by the expression of a panel of chemokine receptors and transcription factors. Notably, in INV TDLNs, a significantly higher proportion of regulatory and conventional $\mathrm{T}$ cells were Th1-polarized $(P<0.05)$. Further functional analysis showed that after ex-vivo PMA/Iono stimulation, the Th1-polarized conventional $\mathrm{T}$ cells, but not the Th1-polarized regulatory $\mathrm{T}$ cells produced high amounts of IFN- $\gamma$, being the IFN- $\gamma$ production significantly higher in INV TDLNs $(P<0.05)$.

\section{Conclusion}

Overall, we observed that immune cells from metastatic TDLNs show evidence of high activation (increased proportion of inflammatory DCs and of Th1-polarized memory $\mathrm{T}$ cells) highlighting their potential role in the anti-tumor immune response.

Published: 6 November 2014

References

1. Cochran AJ, Huang RR, et al: Tumour-induced immune modulation of sentinel lymph nodes. Nat Rev Immunol 2006, Sep;6(9):659-70.

2. Segura E, Valladeau-Guilemond J, et al: Characterization of resident and migratory dendritic cells in human lymph nodes. J Exp Med 2012, 209(4):653-60, Apr 9. 
doi:10.1186/2051-1426-2-S3-P31

Cite this article as: Núñez et al:: Lymph node invasion by tumor cells modifies the distribution of dendritic cell subsets and memory $\mathrm{T}$ cell profiles in human cancer patients. Journal for ImmunoTherapy of Cancer 20142 (Suppl 3):P31.

Submit your next manuscript to BioMed Central and take full advantage of:

- Convenient online submission

- Thorough peer review

- No space constraints or color figure charges

- Immediate publication on acceptance

- Inclusion in PubMed, CAS, Scopus and Google Scholar

- Research which is freely available for redistribution

Submit your manuscript at www.biomedcentral.com/submit 